\title{
Encephalization and Brain Organization of Mobulid Rays (Myliobatiformes, Elasmobranchii) with Ecological Perspectives
}

\author{
Csilla $\operatorname{Ari}^{* 1,2,3}$ \\ ${ }^{1}$ USF Health Byrd Alzheimer's Center and Research Institute, Tampa, Florida 33613, USA \\ ${ }^{2}$ Department of Molecular Medicine, University of South Florida, Tampa, Florida 33612, USA \\ ${ }^{3}$ Semmelweis University, Department of Anatomy, Histology and Embryology, Budapest 1094, Hungary
}

\begin{abstract}
In the present study the brain mass to body mass ratio and external morphological features of the brain of Mobula japanica, Mobula thurstoni and Manta birostris (devilrays) are described. The Mobulids extended the upper boundary of the minimum convex polygon described earlier by other authors for batoids, which is plotted on a double logarithmic scale of brain to body mass, causing some change in the allometric coefficient. The encephalization quotient of Mobulas was higher than unity, therefore it can be concluded that the actual brain mass is greater than expected by the given body mass. $M$. japanica had the highest percentage $(61 \%)$ of telencephalic mass from all batoids, while the brain mass of $M$. birostris was the highest of all fish studied so far. The gross morphology of the enlarged Mobulid telencephalon and cerebellum prominently resembled to that of Sphyrna mokarran (great hammerhead shark). A structural dimorphism of the highly foliated cerebellum was detected between genders of the $M$. japanica, albeit with a small sample size. No such gender-related dimorphism was detected in brain mass/body mass ratio. Other brain parts were similar to those of other elasmobranch species. The data are discussed in terms of their ecological and evolutionary significance.
\end{abstract}

Keywords: Cartilaginous fish, devil ray, morphometry, cerebellum, sexual dimorphism, neuroecology.

\section{INTRODUCTION}

Among batoids, myliobatiform rays possess brains with more advanced features, similar to that of galeomorph sharks, while skates possess features more similar to those of squalomorph sharks [1]. To measure the evolution of the brain among different radiations a well established way is to describe the difference in brain volume or mass. By analyzing the relation of brain mass to body mass, information can be collected on the organization of the brain of a particular animal. Comparison of cerebralization in chondrichthyan fishes with that in other vertebrate groups has been made by constructing minimum convex polygons to enclose data points on a double logarithmic scale of a brain to body mass plot by Jerison [2]. The same method was applied to additional data by Bauchot et al. [3], Ebbesson and Northcutt [4], Northcutt [5, 6], Smeets et al. [7], Myagkov [8], Yopak et al. [9], Lisney et al. [10]. According to such analysis, chondrichthyans exhibit a wide range of cerebralization that is higher than that of cyclostomes [11], falling in the upper range for teleosts and reptiles and in the lower range for birds and mammals $[1,5,6]$. From all the elasmobranchs the highest brain mass/body mass ratio is possessed by the galeomorph sharks and the myliobatiform rays. The most advanced family of the myliobatiformes order is the pelagic, filter-feeder [12] and large-bodied Mobulidae, or 'devil rays', such as Mantas and Mobulas.

*Address correspondence to this author at the USF Health Byrd Alzheimer's Center and Research Institute, Tampa, Florida 33613, USA;

Tel: +1-813-3960606/60712; Fax: +1-813-8661601;

E-mail: csari2000@yahoo.com
Speculations on vertebrate brain evolution became more intense in the last two centuries, after the development of new theories and experimental techniques [13]. In recent publications [8-10] encephalization quotients are also commonly calculated in order to assess which species had relatively larger brains. This ratio expresses the actual brain size as compared to the expected brain size for an animal of a given mass [2].

While more papers discuss different features of shark brains [e.g. 5, 6, 9, 14-17], even of rare species [18-23], batoids seem to have been rather neglected. Only a few data are available on the comparative morphology and the degree of cerebralization of skate and ray brains [8], especially of batoids from the upper portion of the minimum convex polygon $[10,24]$. Only a few basic descriptive anatomical studies have been published connected to the brain of largebodied batoids: A rete mirabile cranica was described as a counter-current heat-exchanger around the brain of Mobula tarapacana and Manta birostris [25-27], brain-body scaling was performed with limited information [24], and recently the astroglial distribution was described in the brain of Mobula japanica [28, 29]. Striedter [24] described that 'devil ray' has the largest brain of any cartilaginous fish, even though its body is considerably smaller than that of the largest sharks (e.g. Cetorhinus maximus), without exact quantitative data supporting this statement.

The brain size of fishes can often be connected to their habitat and lifestyle: the shark species with the largest brains relative to body mass are benthopelagic or pelagic, chiefly found in reef or coastal- oceanic subhabitats [9]. Teleosts living in reef associated habitats have the largest brains [30, 
31] as well, suggesting that the habitat and lifestyle influence the relative brain size. It is also believed that organization of the brain is more similar in species with analogous, but independently evolved lifestyles than those that share taxonomic classification [17]. However, other large bodied pelagic filter-feeder elasmobranchs, such as the basking shark (Cetorhinus maximus), the whale shark (Rhincodon typus), and the megamouth shark (Megachasma pelagios) all possess relatively small brains compared to their body weight [17].

The degree of foliation and symmetry exhibited by the cerebellum in chondrichthyans are also highly variable [5-7, $9,10,32]$, but it is still unclear what is the adaptive significance of these features. In all vertebrate groups, differences in the size, shape and proportions of various brain parts reveal evolutionary changes and reflect adaptations to different ecological niches and conditions of life. The relative development of major brain areas possibly correlates with various ecological factors, such as diet and feeding habits in teleosts [30, 33-37] and in mammals [3841].

To understand more the behavior and capabilities of Mobulids, - myliobatiform rays with the highest body weight- as well as the evolutionary significance of their brain morphology, the description of the main characteristics of their brain is essential. Therefore, the brain mass to body mass ratio and external morphological description of the brain of Mobula japanica (spinetail devilray) [42], Mobula thurstoni (smoothtail devilray) [43] and Manta birostris (giant manta) [44] are presented in this paper.

\section{MATERIALS AND METHODOLOGY}

\section{Specimen Collection}

Data were collected from a total of 13 Mobula japanica (six females and seven males), two male Mobula thurstoni and a female Manta birostris. The animals were identified using the identification guide Mobulidae [45, 46]. The Mobula specimens were caught from the Sea of Cortez by commercial fishermen for commercial reasons at Punta Arenas, Mexico in July 2002. Data and the brains were collected from animals to doom to be discarded after removing flesh. The animal's sex, disk width, body mass (weighed by a suspension scale) and in situ brain morphology were recorded. The level of maturity was determined based on their body size (mass or disc width) or examination of their reproductive organs. Since the relative size of the brain and individual brain areas vary ontogenetically in fishes $[16,36]$ only mature individuals were used for the brain-body weight analyses (five females and five males of $M$. japanica). The brains were removed at 1-5 hours post mortem and immersion fixed in AFA $(90 \mathrm{ml}$ $80 \%$ ethanol, $5 \mathrm{ml}$ formalin, $5 \mathrm{ml}$ glacial acetic acid), which resulted in an 8-9 \% reduction in brain mass. The photograph of the Manta birostris brain was taken of a specimen from R. Glenn Northcutt's collection. The brain of Sphyrna mokarran was kindly provided by Phillip Motta.

\section{Brain Mass}

The brains were analysed after 1-6 months fixation. Data for relative development of major brain divisions were obtained only of $M$. japanica by dissecting two brains into the following brain divisions for weighing (based on Northcutt [6]): telencephalon, diencephalon, mesencephalon, cerebellum, and medulla oblongata. The caudal boundary of the telencephalon was considered to be a plane extending from the rostral border of the optic chiasm. The caudal boundary of the diencephalon was considered to be a plane extending from the rostral pole of the optic tectum to the caudal pole of the infundibulum. The cerebellum was considered to include all tissues lying dorsal to a rostrocaudal plane just below the ventral lip of the cerebellar auricle. The caudal boundary of the medulla was set at the level of the first complete cervical spinal nerve. All cranial nerves were transected within $3 \mathrm{~mm}$ from their base, and neither these, nor the meninges, blood vessels, olfactory bulbs and peduncles, connective tissue, and choroids plexus of the fourth ventricle were included in the brain division masses.

Each brain and their divisions were blotted immediately before being weighed to the nearest $0.01 \mathrm{~g}$. Brain masses were not corrected for shrinkage due to fixation. A Scaletec SPB53 analytical balance was used for all measurements. The accuracy of 10 repeated measurements on small brain divisions was $\pm 0.01 \mathrm{~g}$. The relative sizes of each of the brain areas were expressed as percentages. For comparison, additional data on batoid brain and body masses were used from previous publications $[5,6,8,10]$, which represented 35 species. Data on Manta birostris brain and body masses were kindly provided by Georg Striedter.

\section{Encephalization Quotient}

The encephalization quotient (EQ) expresses the ratio of the actual brain size to the expected brain size for an animal of a given mass [2]. It shows whether the relative brain mass is greater than $(\mathrm{EQ}>1)$, average $(\mathrm{EQ}=1)$, or less than expected $(\mathrm{EQ}<1)$ for its body mass.

$\mathrm{EQ}=\mathrm{Ea} / \mathrm{Ee}$

where $\mathrm{Ea}=$ actual brain mass and $\mathrm{Ee}=$ expected brain mass Ee was calculated using the following allometric equation:

$\mathrm{y}=\mathrm{ax}^{\mathrm{b}}$

where $y=$ brain mass, $x=$ body mass, $a$ is the cephalization coefficient, and $\mathrm{b}$ is the allometric coefficient.

The raw species data were plotted on logarithmic coordinates and the linear regression line describing the allometric relationship was calculated using the least squares regression using the equation:

$\log y=\log a+b \log x$

The cephalization and allometric coefficients were determined originally on the basis of the collected data on 35 batoid species by Northcutt [5, 6], Myagkov [8] and Lisney [10]. Where more data from the same species were found, those were all used as independent data points. The same equation was used when the Mobulid brain mass and body mass data, as independent data points, as well as the mean value of Mobulids were included and the new allometric coefficients were determined, and the changes in the regression lines were compared. 


\section{Macroscopic Morphology}

For the macroscopic morphological description, five mature female and five mature male $M$. japanica brains were examined, in addition to two $M$. thurstoni and a $M$. birostris brains. The terminology of the brain structures was given according to Smeets et al. [7]. Photographs of the brains were taken by a Fuji Finepix 2600 camera. For statistical analyses Matlab software was used and unpaired, nonparametric, two-tailed Mann-Whitney test. (Significance level was $\mathrm{p}<0.05$ ).

\section{Cerebellar Foliation Index}

Cerebellar foliation was quantified using the visual grading method $[9,17]$. It was applied in order to assess the degree of foliation and structural complexity exhibited by the cerebellar corpus on shark brains. The foliation of the cerebellar corpus was graded from 1-5, based on the smoothness of the cerebellar surface, symmetry, depth and degree of branching of the grooves. Diagrams were drawn from the selected cross sections of $M$. japanica brain at 0,9 $\mathrm{cm}$ intervals.

\section{Histological Processing}

Hematoxylin eosin staining was performed on $M$. japanica brain sections to identify basic brain regions according to the following procedure. M. japanica brains were dehydrated by storing in $80 \%$ ethanol for 7 days, $90 \%$ ethanol for 7 days, $96 \%$ ethanol for $2 \times 7$ days, $100 \%$ ethanol for $3 \times 1$ days, $1 \%$ celloidin methylbenzoate for 1 and 2 days, and xylene for $2 \times 1$ hours. Before embedding the brain was stored in paraplast: xylene mixtures $(1: 2,1: 1$ and 2:1), each for half an hour, followed by paraplast for 12 hours, than for 1 day twice. The brains were embedded in paraplast (Sigma, Paraplast Plus P3683). Serial coronal sections $(10 \mu \mathrm{m}$ thick) were sectioned by a Reichert microtome and mounted on slides coated with albumin or gelatine. To demonstrate the macroscopic structure, drawings were made of hematoxylin eosin stained sections using a microscope slide projector apparatus. The identification and nomenclature of brain structures are based on the descriptions of Northcutt [5, 6], Butler and Hodos [1], Smeets et al. [7] on the brain of Hydrolagus collei (Holocephali), Squalus acanthias, Scyliorhinus canicula and Raja clavata.

\section{RESULTS}

\section{Mass Ratios and Encephalization Quotient}

The mean total body mass of females was $61.76 \pm 5.83 \mathrm{~kg}$ $(\mathrm{M} \pm$ S.E.), whereas the mean total brain mass was $58.80 \pm 3.96 \mathrm{~g}(\mathrm{M} \pm \mathrm{S}$.E. $)$ for M. japanica. The average total body mass in males was $58.06 \pm 4.48 \mathrm{~kg}$, the average total brain mass was $52.89 \pm 2.41 \mathrm{~g}$. The average total body mass was $59.60 \pm 3.44 \mathrm{~kg}$, the average total brain mass was $55.35 \pm$ $2.24 \mathrm{~g}$. There was no significant difference between the body masses of the genders $(\mathrm{p}=0.3434)$, or between the brain masses of the genders $(\mathrm{p}=0.34)$. The average brain mass for M. thurstoni was $62.5 \pm 0.9 \mathrm{~g}$ with $65.5 \pm 2.3 \mathrm{~kg}$ body mass, while the M. birostris possessed $122 \mathrm{~g}$ brain weight with $165 \mathrm{~kg}$ body weight, the highest brain weight of all fish studied so far.
The mass of the brain parts as percent of total brain mass in $M$. japanica were as follows: telencephalon $61 \%$, diencephalon $4.8 \%$, mesencephalon $6.2 \%$, body of cerebellum $19.05 \%$, medulla oblongata $8.95 \%$. The most prominent brain parts were the telencephalon and the cerebellum in all three Mobulids.

The brain and body mass of Mobulids were compared to other batoids from the studies of Northcutt [5, 6], Myagkov [8], Lisney et al. [10]. Using 35 batoids as independent data points, the dependent variable (brain mass) increased with the independent variable (body mass) according to the allometric relationship

$y=0.652 x+0.397\left(r^{2}=0.67, n=35\right.$, Fig. 1A)

After including the Mobulid specimens as independent data points in the original dataset, the allometric equation changed to:

$y=0.735 x+0.396\left(r^{2}=0.89, n=48\right.$, Fig. 1B $)$

After including the Mobulids using their mean values, the allomentric relationship was:

$y=0.725 x+0.396\left(r^{2}=0.68, n=36\right.$, Fig. 1C $)$

Thus, the newly defined data point changed the slope of the regression line by making it steeper. The Mobula and Manta brain mass/body mass data modified the minimum convex polygon of batoids by extending its upper boundary (Fig. 1C).

On the basis of the new equation (where Mobulids were represented by their mean value) the expected brain weight for Mobulas would be $45.9 \mathrm{~g} \quad(\mathrm{EQ}=1.303)$, for Mantas $120,02 \mathrm{~g}(\mathrm{EQ}=1,02)$, therefore the actually measured Mobula brain masses were greater than expected for their body mass, while the Manta brain mass was almost identical to what was expected.

\section{Gross Morphology}

The macroscopic structure of $M$. japanica brain was studied (Figs. 2-4) in more details as a reference to the other two species. The average brain size was $9.53 \mathrm{~cm} \pm 1.16 \mathrm{~cm}$ $(\mathrm{M} \pm$ S.E.) in length, measured from the rostral tip of the telencephalon (Fig. 2A-C) to the end of the rhomboid fossa, after fixation. The maximum width was $5.52 \mathrm{~cm} \pm 0.21 \mathrm{~cm}$ at the level of telencephalon, whereas the maximum height was found to be $4.55 \mathrm{~cm} \pm 0.36 \mathrm{~cm}$ at the level of cerebellum (Fig. 2A, B). The large cranial cavity (Fig. 2D) may be explained by the fact that the brain and the cranial cavity have different rates of growth. The most prominent brain parts were the huge telencephalon and the convoluted and strongly foliated cerebellum (Figs. 2, 3). In the ensuing description five major brain subdivisions were characterized: telencephalon, diencephalon, mesencephalon, cerebellum, medulla oblongata, in addition to the spinal cord and the cranial nerves.

\section{Telencephalon}

From a dorsal perspective (Fig. 2A), the telencephalon was almost circular, compact formation with laterally attached, relatively thin olfactory tracts in the rostroventral region. The hemispheres were fused completely creating bulges in the dorsal surface contrasting to a median 

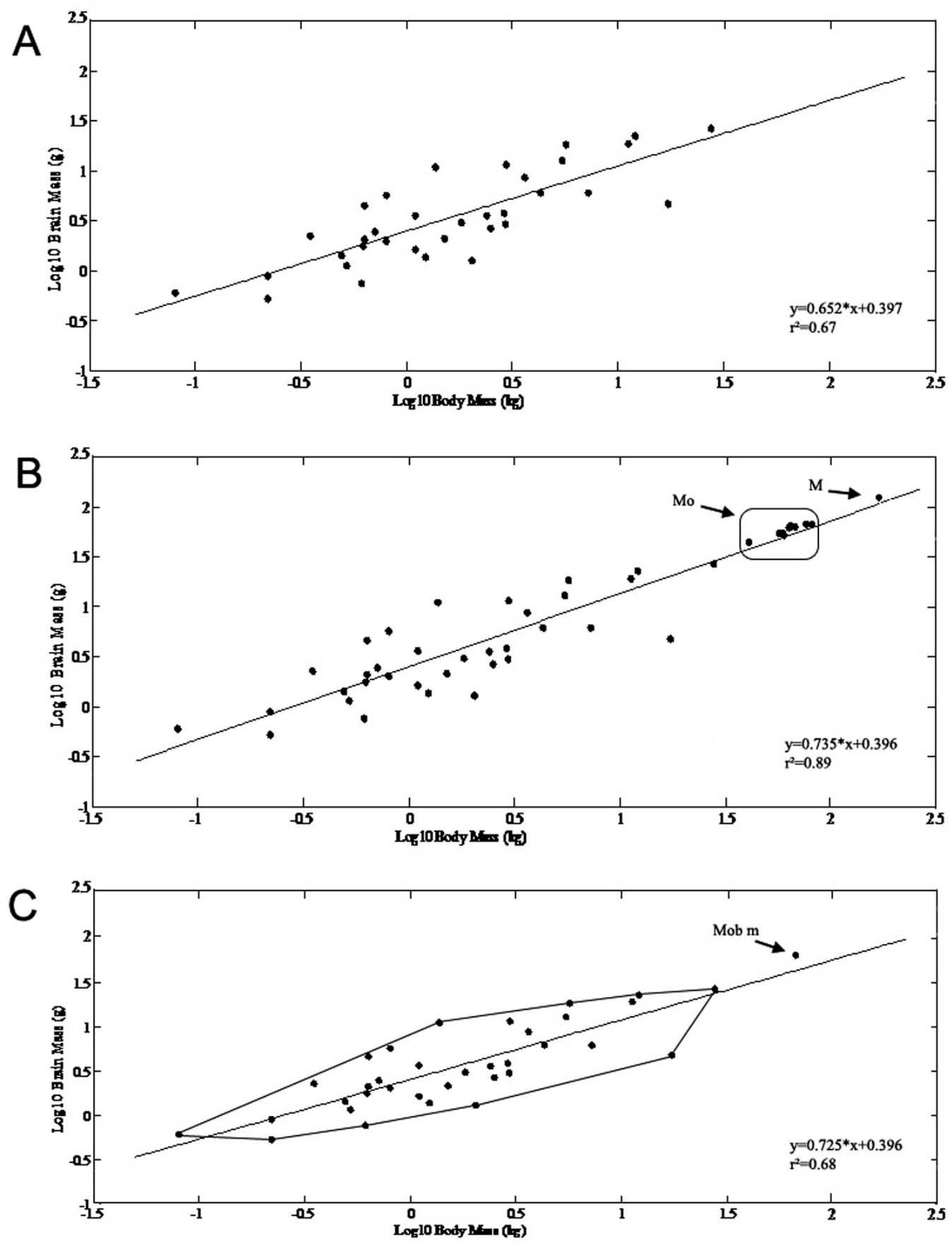

Fig. (1). The allometric equations and their changes are presented after including the Mobulid specimens as independent data points and as their mean value. $\mathrm{X}$ axis: $\log$ (body mass in $\mathrm{kg}$ ), Y axis: $\log$ (brain mass in $\mathrm{g}$ ). A) Brain mass and body mass correlation presented on double logarithmic scales for batoids based on data from previous studies $[5,6,8,10]$. Using 35 batoids as independent data points, the dependent variable (brain mass) increased with the independent variable (body mass) according to the allometric relationship: $\mathrm{y}=0.652 \mathrm{x}+0.397$ $\left(r^{2}=0.67, n=35\right)$. B) Scaling of brain mass with body mass of the Mobulas (Mo) and Manta (M) specimens as independent data points in addition to the previously described species. After including the Mobulid specimens as independent data points in the original dataset, the allometric equation changed to: $y=0.735 \mathrm{x}+0.396\left(\mathrm{r}^{2}=0.89, \mathrm{n}=48\right)$. C) The original minimum convex polygon for batoids is presented in addition to the mean value of Mobulids (Mob m) extending the original polygon. After including the Mobulids using their mean values, the allomentric relationship was: $y=0.725 x+0.396\left(r^{2}=0.68, n=36\right)$ Thus, the newly defined data point changed the slope of the regression line by making it steeper. The Mobula and Manta brain mass/body mass data modified the minimum convex polygon of batoids by extending its upper boundary. 

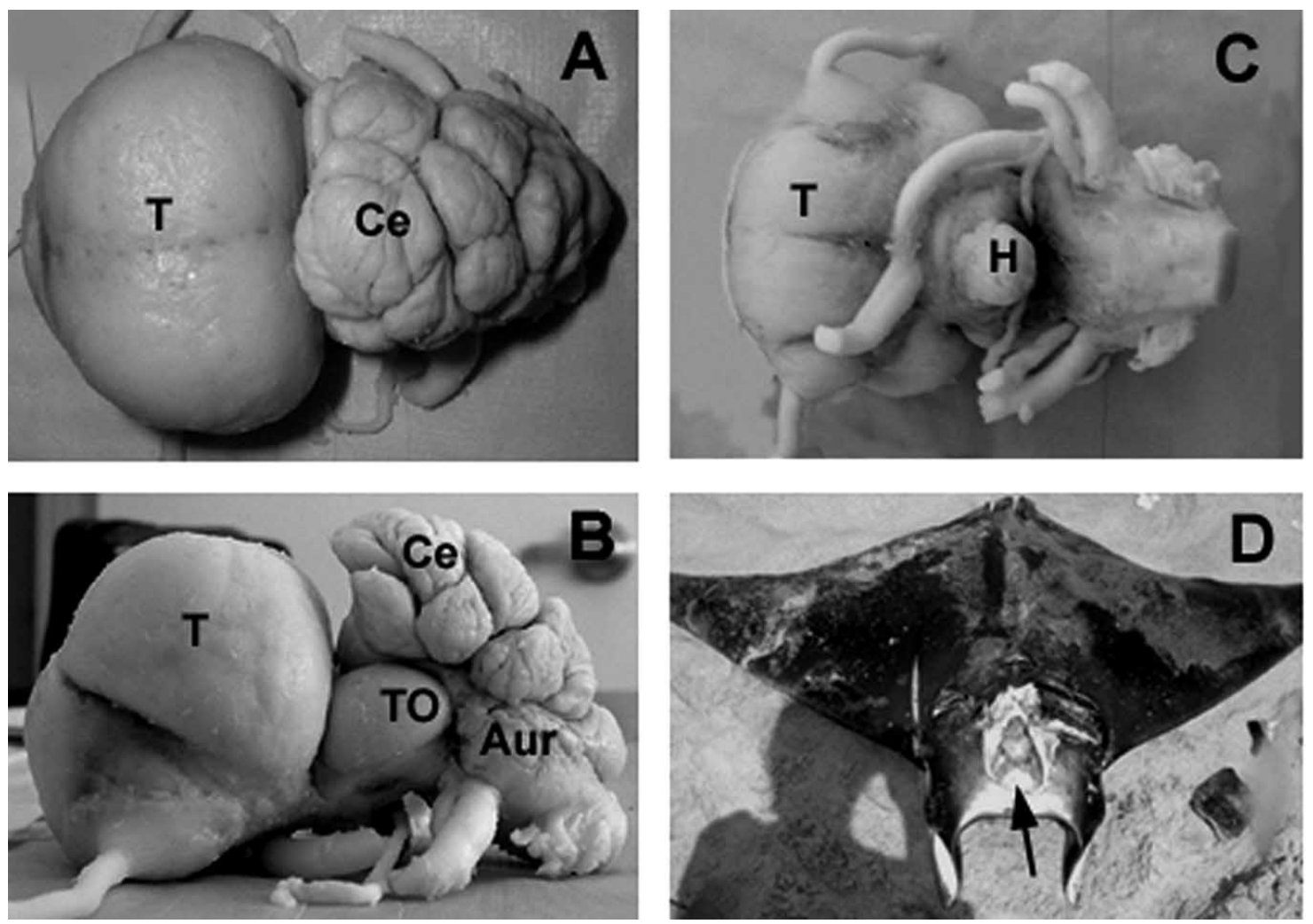

Fig. (2). M. japanica brain from dorsal (A), lateral (B) and ventral (C) aspects. M. japanica brain in situ (D), note the voluminous chondrocranium (arrow). T-telencephalon; Ce- cerebellum; TO- tectum opticum; Aur- auricula cerebelli; H- hypophysis.

depression, while real median hemispheric fissure could not be observed. From the dorsal aspect, a small protuberance could be seen on the rostroventral part of the telencephalon, separated from the rest of the telencephalon by a deep sulcus. From a lateral perspective (Fig. 2B), this sulcus could be observed in about the middle of the almost oval-shaped telencephalon. Lateral lobes surrounded the site where the olfactory tracts attached to the telencephalon, which lobes could be observed from lateral and ventral aspects as well. From a ventral perspective (Fig. 2C), the telencephalon appeared nearly square-shaped. A median longitudinal sulcus could be seen separating the two hemispheres and was divided into two branches caudally. The occipital regions of the base of the telencephalon were covered by the optic nerves and the relatively large optic chiasm.

\section{Diencephalon and Mesencephalon}

From the ventral perspective, the chiasm, hypophysis, lateral parts of the inferior lobes of the hypothalamus and parts of the optic tectum could be seen (Fig. 2C). The optic tectum was large (Fig. 2B), as observed from the lateral perspective but it was completely covered by the cerebellum from the dorsal perspective.

\section{Cerebellum}

The cerebellum of $M$. japanica consisted of a medial, unpaired corpus cerebelli and laterally situated paired auricles, like in other chondrichthyans. The dorsal aspect of the cerebellum was extremely enlarged, overlying the rostral part of the rhomboid fossa (Fig. 2A).
The cerebellum of M. japanica was highly foliated, and it could be divided by deep sulci into 2 lobes: anterior and posterior.

The anterior lobe of the cerebellar corpus was the largest, divided into rostral, intermediate and caudal subdivisions, which exhibited extremely complex foliation. The position of these subdivisions varied, and their orientation with respect to the longitudinal axis followed different patterns. The rostral subdivision of the anterior lobe was divided into more sublobuli and was positioned either along the midline or on its left side. The intermediate subdivision of the anterior lobe was also divided by sulci into more sublobuli and was positioned either along the midline or on its right side. The caudal subdivision of the anterior lobe was always smaller than the other subdivisions, yet highly foliated and lied either along the midline or on its either side. The posterior lobe was less foliated, and it lied unvariedly in the midline.

The auricles were small and flat structures on the ventrolateral side of the corpus cerebelli. Sulci longitudinales laterales could not be recognized.

The M. japanica exhibited the highest grade (5) of cerebellar foliation index, according to the visual grading method of Yopak et al. [9] applied for shark cerebellum. The features of grade 5 are: extremely foliated, with deep and branched grooves, distinctive cerebellar sections, and cerebellar asymmetry.

On the basis of symmetry and the number of folds a difference could be observed in the foliation of cerebellum between genders (Fig. 4). The following gender differences 

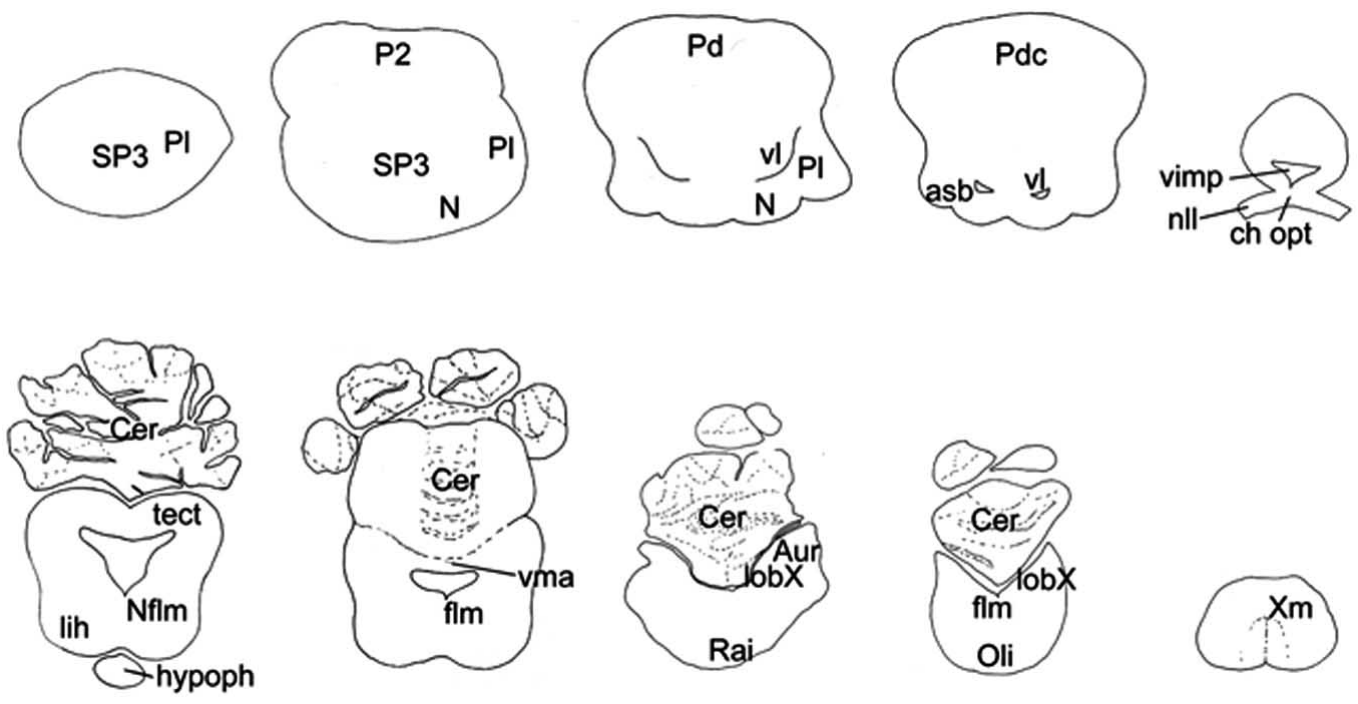

Fig. (3). Diagrams of M. japanica brain in a rostrocaudal sequence based on selected transverse sections cut at $0.9 \mathrm{~cm}$ intervals. Certain brain regions were labeled for orientation. asb - area superficialis basalis; Aur - auricula cerebelli; Cer - cerebellum; ch opt - chiasma opticum; $\mathrm{flm}$ - fasciculus longitudinalis medialis; hypoph - hypophysis; lih - lobus inferior hypothalami; lobX - lobus vagi; N - nucleus N; Nflm nucleus fasciculi longitudinalis medialis; $\mathrm{nII}$ - nervus opticus; Pd - pallium dorsale; Pdc - pallium dorsale (centrale); Pl - pallium laterale; P2 - pallial area 2; Rai - nucleus raphes inferior; SP3 - subpallial area 3; tect - tectum opticum; Oli - oliva inferior; vimp - ventriculus impar; vl - ventriculus lateralis; vma - velum medullare anterius; Xm - nucleus motorius nervi vagi.

could be discerned: i) the rostralmost part of the female cerebellum (rostral subdivision of the anterior lobe) was asymmetric, larger on the left side with rostro-caudally oriented parallel sulci; ii) the rostralmost part of the male cerebellum was more symmetric, and a large elevation could be found in its middle part. The sulci were irregularly arranged here. In general, the arrangement of foliation seemed more symmetric in males and less symmetric in females.

\section{Medulla Oblongata}

The dorsal opening of the IVth ventricle, the rhomboid fossa was completely covered by the caudal part of the cerebellum. After removing the cerebellum from the top of the rhombencephalon, the somatomotor and visceromotor column could be visible. From the lateral aspect the walls of the rhomboid fossa were relatively high. The rhombencephalon became narrower caudally.

\section{Spinal Cord}

The spinal cord was slightly flattened in a dorsoventral direction, and the median fissures could be seen on the ventral perspectives as well.

\section{Cranial Nerves} Table 1.

The general description of the cranial nerves is shown on

\section{Interspecific Differences}

The dorsal bulge of the telencephalon in M. thurstoni was less round and prominent than in M. japanica (Fig. 5A). The cerebellum showed similar foliation pattern with less deep sulci on the anterior lobe. M. thurstoni also possessed a significantly smaller optic tectum and more elongated medulla oblongata.
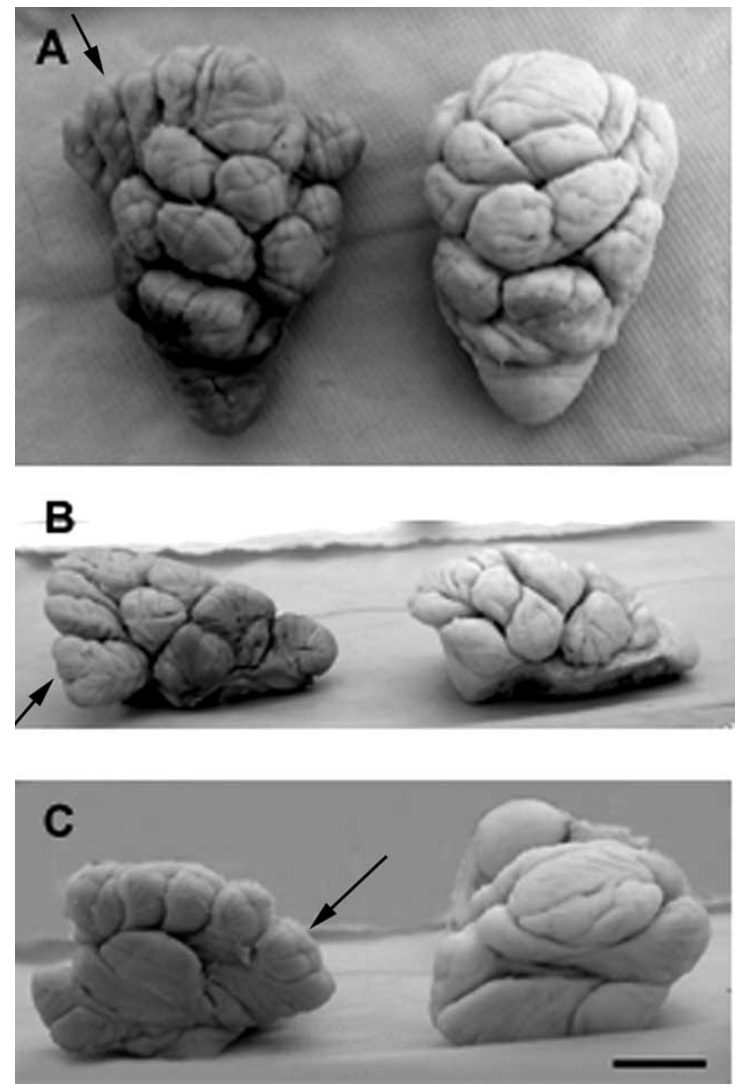

Fig. (4). On the basis of the symmetry and the number of folds there was difference in the foliation of cerebellum between genders. Female on the left sides, male on the right on the photographs taken from dorsal (A), lateral (B) and rostral (C) aspects. The arrows are pointing at the most distinct, assymetric part of the anterior lobe of the cerebellum in females with more paralell sulci than it could be observed in males. Scale bar: $1.2 \mathrm{~cm}$. 
Table 1. Diameter and the Place of Origin of $M$. japanica Spinal Nerves

\begin{tabular}{|c|c|c|c|}
\hline Nerves & & Diameter $(\mathbf{m m})$ & Place of Origin \\
\hline \hline I. & olfactory & relatively thick, $2 \mathrm{~mm}$ & rostroventral part of the telencephalon \\
\hline II. & optic & very thick, $2.5 \mathrm{~mm}$ & ventral side of the telencephalon, from the chiasma opticum \\
\hline III. & oculomotor & relatively thin, $1 \mathrm{~mm}$ & behind the hypophisis \\
\hline IV. & trochlear & very thin, $0.5 \mathrm{~mm}$ & rostrolateral part of the rhombencephalon \\
\hline V. & trigeminal & middle size, $1 \mathrm{~mm}$ & could not be observed \\
\hline VI. & abducens & & could not be observed \\
\hline VII. & facial & & rostrolateral part of the rhombencephalon, behind the nerve V. \\
\hline VIII. & statoacoustic & very thick, $3 \mathrm{~mm}$ & caudolateral part of the rhombencephalon \\
\hline IX. & glossopharyngeal & thin, $1.5 \mathrm{~mm}$ & caudolateral part of the rhombencephalon \\
\hline X. & vagal & thick, $2.5 \mathrm{~mm}$ & \\
\hline
\end{tabular}

The telencephalon of $M$. birostris was rather similar to $M$. japanica with huge, rounded dorsal bulge (Fig. 5B). The cerebellum of the Manta specimen was found to be more foliated with deeper sulci than of $M$. japanica and a large optic tectum could also be observed.

\section{DISCUSSION}

This is the first study describing the brain organization and detailed brain-body scaling of three large bodied batoid species, Mobula japanica, Mobula thurstoni and Manta birostris.

\section{Brain Mass/Body Mass}

The position of the Mobulid brain was determined in the minimum convex polygon of brain weight/body weight ratio and compared to sharks of similar brain size and those with similar life style and feeding strategy (filter feeding).

Chondrichthyans have been found to possess large brains in relation to other vertebrates and the brain mass/body mass ratio has received attention in the last few decades $[8,47-$ $50]$. Northcutt $[5,6]$ measured brain mass/body mass ratios in several species of chondrichthyans, including batoids, and derived a minimum convex polygon from the data. Myagkov [8] included some additional species, yielding similar polygons. While the coefficient of allometry of large-bodied sharks has been calculated by Myagkov [8], Demski and Northcutt [51], and Yopak et al. [9], large-bodied batoid referred as 'devil ray' has been included only in a chondrichthyan polygon with limited information by Striedter [24]. The three Mobulid species presented in the present study did extend the upper boundary of the batoid minimum convex polygon, as well as the chondrichthyan minimum convex polygon described earlier.

According to the encephalization polygons, the encephalization level of cartilaginous fishes exceeds that of cyclostomata, teleosts, amphibians and other primitive vertebrates. The allometry coefficient values determined by Myagkov [8] were as follows: in Agnatha 0.2-0.4, in Gnathostomata 0.49-0.66, and in human 0.93 .

Large brains were correlated with habitat, lifestyle, and cognitive capabilities in a variety of vertebrate groups [15, $24,36,52,53]$, including chondrichthyans $[5,6,9,10,30]$. It is believed that the organization of the brain is more similar in species with analogous but independently evolved
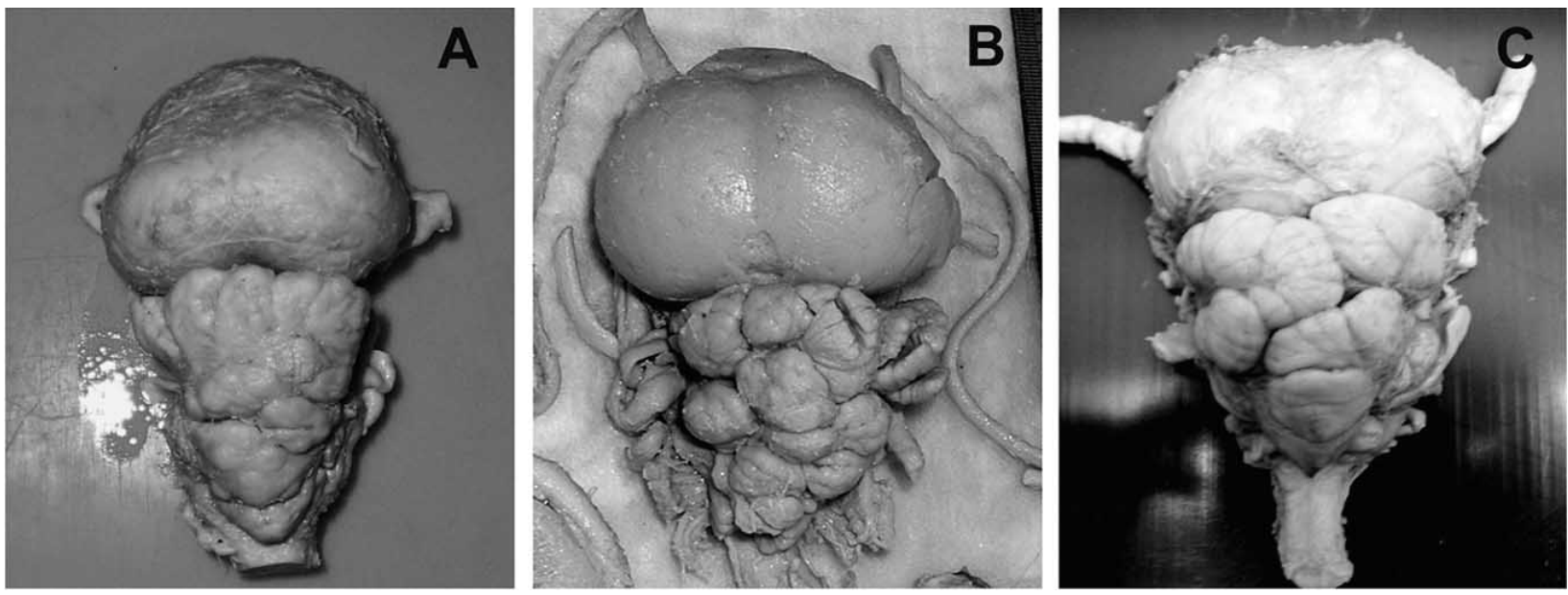

Fig. (5). The brain of Mobula thurstoni (A), Manta birostris (B) and Sphyrna mokarran (C) are presented in dorsal aspects. Note the similar shape and degree of foliaton of the telencephala and cerebella in Mobulids and Sphyrnids inspite of their very different feeding strategies. For comparison see Fig. (2A) for M. japanica brain. 
lifestyles than those that share taxonomic classification [17], although this hypothesis does not completely fit on large bodied filter feeder elasmobranchs. Comparing 35 other batoid species Mobulids demonstrated a large brain compared to their body size, unless other large bodied plankton feeder shark species. The large bodied and plankton feeder basking shark (Cetorhinus maximus) [54] extended the lower boundary [47] of the brain mass/body mass minimum convex polygon for cartilaginous fishes. Rhincodon typus and Megachasma pelagious were found to have small brain relative to their body weight as well [17]. However, the large bodied and plankton feeder batoids extended the upper boundary of the batoid polygon and were present in the upper portion of the polygon for cartilaginous fishes. The relatively small brains of planktivorous predators were related to their opportunistic passive predation strategies [17], which might be less demanding cognitively in terms of sensory and/or motor requirements in comparison to more agile hunters [9, 47, 55], however Mobulids possessing large brains do not support this hypothesis. Although, the enlargement of their brain is most likely associated with their complex behaviors and 'social intelligence' and not with their foraging strategy $[17,24,36]$.

The brain mass was found to increase with body mass in phylogenetic level among sharks by Yopak et al. [9]. Comparison of the encephalization quotients of mature sharks of similar body mass (Carcharhinus leucas) [42], body mass $=54.36 \mathrm{~kg}, \mathrm{EQ}=0.92 ;$ Sphyrna lewini [56], body mass $=59.88 \mathrm{~kg}, \mathrm{EQ}=1.38$ by [6] and the Mobula $(59.6 \mathrm{~kg}$, $\mathrm{EQ}=1.303$ ) supports the idea that a greater brain mass can be the consequence of a larger body size in elasmobranchs. In fact, in the present study, the actual brain mass of mature $M$. japanica seemed to be even larger than it would be expected from the given body mass. However, it has been demonstrated by Marino [57] that similar levels of encephalization can emerge in very different phylogenetic lineages by reporting that some odontocetes, such as Tursiops truncatus possess significantly higher EQ levels than all anthropoid primates except Homo sapiens. For comparison of brain and body masses between relevant elasmobranch species see Table 2 .

The brain mass/body mass ratio can also change with age and maturity [8]. For Elasmobranchii, already investigated at ontogenetic level [58, 59], a remarkable decrease in the relative brain mass takes place together with an increasing body mass, which is typical for other primary aquatic vertebrates, first of all fishes $[60,61]$. According to Lisney et al. [16] ontogenetic shifts occur in the size of sensory brain areas during brain development in elasmobranchs. Thus, the relative brain mass are comparable between species of similar maturities. To eliminate this factor, the Mobulids studied in this paper have all reached their maturity.

In further studies a direct correlation has been found between large brain size and complex behaviour in bony fishes [62] and reptiles [63, 64]. It is suggested that the requirements for learning the complex spatial organization of the reef habitat might have influenced the evolution of brain size $[6,30,50]$. This correlation seems to be true among batoids as well, since mobulid rays are pelagic and they mostly live in coastal habitats where it is most likely a selective advantage if they are able to learn the complex spatial organization $[6,9,30,50]$.

Table 2. Comparison of Brain and Body Masses Between Relevant Elasmobranch Species

\begin{tabular}{|c|c|c|}
\hline & Body Mass (kg) & Brain Mass (g) \\
\hline \hline Megachasma pelagios & 1040 & 19.8 \\
\hline Cetorhinus maximus & 385 & 20.7 \\
\hline Rhincodon typus & 1388.115 & 35.435 \\
\hline Squalus acanthias & 4.2 & 3.87 \\
\hline Carcharhinus leucas & 83.8 & 54.36 \\
\hline Sphyrna mokarran & 148.5 & 99.14 \\
\hline Galeocerdo cuvieri & 200 & 107.5 \\
\hline Dasyatis americana & 27.5 & 26.45 \\
\hline Mobula japanica & 59.6 & 55.35 \\
\hline Manta birostris & 165 & 122 \\
\hline
\end{tabular}

The brain and body masses of three large bodied filter-feeding shark species, with similar lifestyle and feeding strategy: Megachasma pelagios [55], Cetorhinus maximus [47], Rhincodon typus [17], a more ancestral squalomorph shark Squalus acanthias [5], and galeomorph sharks from the upper portion of the polygon: Carcharhinus leucas [5], Sphyrna mokarran [9], Galeocerdo cuvieri [5], a ray from the upper portion of the polygon: Dasyatis americana [8] compared to the body and brain mass of Mobula japanica and Manta birostris.

Kotrschal et al. [36] suggested that the increase in relative brain size is related to complex social behaviours and intra- and interspecific interactions. This kind of 'social intelligence' has been correlated with brain size also in birds and mammals $[9,24]$. The cognitive abilities of cartilaginous fishes have been scarcely studied, however, carcharhinid and sphyrnid sharks are considered to be social animals [65-67] that often form true schools. Their enlarged brain might be related to complex social and reproductive behaviours, such as dominance hierarchies and courtship behaviour $[9,65]$. Mobulas also form schools [12, 45], but there is only a single report describing the complex courtship behaviour of Manta birostris [68].

Endothermy, as the elevation of body temperature by metabolic heat production represents one of the most significant developments during vertebrate evolution [69] that might be connected to enlarged brain size [6]. Sharks in general are poikilothermic, but some shark species (Isurus and Lamna) are homeothermic as they are able to maintain body temperatures well above ambient temperature of environment [70] by countercurrent flow of blood at certain places of their body. Among Mobulid rays, in Mobula tarapacana and Manta birostris, a rete mirabile cranica as a countercurrent heat-exchanger has been described around their brain [25-27]. Interestingly, the same families are also characterized as large-brained elasmobranchs in which these unique adaptations might serve to enhance their ability to exploit cooler environments (either deeper water or at higher latitudes) with greater efficiency by slowing the rate of metabolic heat loss to the environment or allowing them higher activity level.

Relative brain size was proposed to be related to the mode of reproduction by Northcutt [6]. Mobulas have 
gestation periods as long as two years [71] and species in the families of carcharhiniforms, sphyrnids, dasyatids and myliobatids evolve yolk sac placentae or placental analogs (trophonemata), increasing energy flow to the embryos by 800 to $5000 \%$ [71]. The same families have the most complex neural organization and the highest brain mass/body mass ratios known for elasmobranchs [6].

The Mobulid brain organization (especially M. japanica) was most similar to the Sphyrnid shark's (Sphyrna mokarran, Fig. 5C), that are active hunters living in a 3dimensional environment (pelagic) and show potential for social behaviour. These sharks with the highest level of neural development showing greatly hypertrophied telencephalons and cerebella (Sphyrna mokarran 67\%) [9] live in reef habitats, while an increase in the relative size of the telencephalon is believed to be associated with complex environment, like in many other vertebrates [24, 34, 72, 73]. Interestingly, both Mobulids and Sphyrnid sharks have an extremely broad head, that probably plays an important role increasing the efficiency of different sensation modalities and their complex integration. The high brain weight/body weight ratio, similar brain organization, the enlargement of the telencephalon and cerebellum, the highly and similarly foliated cerebellum in Sphyrnids and Mobulids represent an independent and convergent evolution, although their feeding habits are very different and they are distantly related.

Various neuroanatomical measures, such as absolute size, progression index, EQ and residual measures were compared by Deaner et al. [74] as assays of cognitive ability in nonhuman primates. They however found that total brain size, which show positive correlations with body size, predicted cognitive variables across non-human primate genera better than residual or EQ measures, which control for body size and therefore not correlated with it. They suggested future comparative studies to employ (log) brain size as a proxy for cognitive abilities. Based on this theory manta rays (with the largest brain among fishes) and mobulids in general should possess the most developed cognitive abilities among batoids (or among fishes) based on their brain size, however we have very limited data on this topic, since only one study described the learning and sensory abilities of a captive manta ray, Manta birostris [75]. The brain weight of Manta birostris is comparable to the primate siamang (Symp syndactylus) [57] suggesting similar cognitive abilities, although these assumptions should be considered carefully, since due to 'aquatic weightlessness' fishes are able to obtain much larger body sizes than terrestrial animals without a similar increase in neural tissue [57].

\section{Telencephalon}

The telencephalon constitutes the highest percentage of total brain mass in Mobula, and Mobula telencephalon shows the highest percentage of all batoids studied so far, even greater than the value found in holocephalans and squalomorph sharks (see Table 3). Of the sharks only the galeomorph Sphyrna mokarran [76], Carcharhinus amblyrhynchos [77], Carcharhinus falciformes [42] have larger telencephalic percentages than Mobula.

An advanced level of brain evolution in sharks and batoids may be best indicated by features like the size of the telencephalon, an expanded and well differentiated nonolfactory telencephalic pallium, especially the central nucleus and medial pallium [6]. In Mobula, a hypertrophy of the inner portion of the dorsal pallium occurs (Fig. 3), termed central nucleus, like in other batoids [14]. Visual, electrosensory, acoustic and tactile projections converge in the central nucleus from several thalamic nuclei [78]. The development of the central nucleus has been linked to complex social behaviors such as dominance hierarchies and other forms of 'social intelligence' [51]. An enlarged central nucleus of the dorsal pallium has been recorded in

Table 3. Percentages of Brain Subdivisions of Total Brain Mass in Relevant Elasmobranch Species

\begin{tabular}{|c|c|c|c|c|c|}
\hline & Telencephalon & Diencephalon & Mesencephalon & Cerebellum & Medulla Oblongata \\
\hline Hydrolagus colliei & 33.3 & 6.5 & 15 & 22.6 & 22.6 \\
\hline Squalus acanthias & 25.5 & 7.5 & 15.9 & 21.3 & 29.8 \\
\hline Carcharhinus taurus & 30.57 & 11.42 & 9.47 & 25.28 & 23.26 \\
\hline Sphyrna lewini & 53.75 & 4.44 & 6.53 & 23.71 & 11.57 \\
\hline Raja eglanteria & 33 & 7 & 13 & 18 & 29 \\
\hline Myliobatis freminvillii & 44 & 5.6 & 10 & 23 & 18 \\
\hline Mobula japanica & 61 & 4.8 & 6.2 & 19.05 & 8.95 \\
\hline Sphyrna mokarran & 67 & 3 & 4 & 18 & 8 \\
\hline Carcharhinus amblyrhynchos & 64.23 & 4.73 & 8.3 & 13.07 & 9.67 \\
\hline Carcharhinus falciformes & 63.48 & 4.99 & 8.31 & 12.53 & 10.68 \\
\hline Alopias superciliosus & 27.19 & 3.15 & 16.19 & 32.09 & 21.39 \\
\hline Alopias vulpinus & 26.79 & 1.66 & 15.6 & 30.6 & 33.02 \\
\hline Cetorhinus maximus & 34 & 7 & 9 & 30 & 20 \\
\hline
\end{tabular}

Holocephalimorph: Hydrolagus colliei [6]; benthopelagic sharks: Squalus acanthias [6], Carcharhinus taurus [9]; galeomorph, pelagic shark: Sphyrna lewini [9]; batoids: Rajiformes: Raja eglanteria [6], Myliobatiformes: Myliobatis freminvillii [6], and Mobula japanica. Sharks with larger telencephalon: Sphyrna mokarran [9], Carcharhinus amblyrhynchos [9], Carcharhinus falciformes [9]. Sharks with larger cerebellum: Alopias superciliosus [9], Alopias vulpinus [9], Cetorhinus maximus [47]. 
Cetorhinus maximus [47] while documented sightings of large numbers of whale sharks have been reported by divers and fishermen. Among Mobulids, Mobula aggregations have been observed while hunting schools of fish in organized groups, as well as Manta feeding aggregations with as many as about 100 individuals were observed (personal observation, personal communication with Anne-Marie Kitchen-Wheeler, Guy Stevens and Douglas Seifert). In addition Manta rays gather in groups during courtship activity [68], but very limited data is available on other aspects of their social behavior.

Primary olfactory projections are restricted to lateral and ventral telencephalic areas, while mechanoreceptive and electroreceptive lateral line sensory modalities reach the chondrichthian forebrain as well. Because of their multimodal input as integrating information received by the various sensory systems, such as olfactory, visual, auditory, as well as mechanoreceptive and electroreceptive lateral line information, and influencing motor behaviour, the chondrichthian telencephalon is often considered as a higherorder coordinating centre [7].

The telencephalon, as percentage of total brain mass, amounts to $24-31 \%$ in squalomorph sharks, 35-67\% in galeomorph sharks $[5,6,8,9], 29.03-60.6 \%$ in batoids $[5,6$, $8,10]$, while in Mobula this value was $61 \%$.

\section{Cerebellum}

The cerebellum is a conservative structure found in all gnathostomata. Among Teleostei, the size of the cerebellum is relatively large in Mormyrids, and they are noted for their use of electricity and sound [24]. This part of the brain in chondrichthyans is relatively large compared to that of most of other vertebrates [79]. It is suggested that the cerebellum modulates motor tasks $[48,80]$ and error correction $[81,82]$ or it is involved in the coordination of target tracking and the analysis of the consequences of organisms' own movements, rather than the control of these movements themselves [9, 83]. The cerebellum constituted a relatively high percentage $(19,05 \%)$ of the total brain mass in Mobula.

The surface of the cerebellar corpus is smooth in holocephalans, squatinomorph and squalomorph sharks (Fig. 6A, B), while some parts of the cerebellar cortex undergo hypertrophy in the advanced galeomorph sharks (Fig. 6C) and the myliobatiforms (Fig. 6D) [1]. They have evolved independently a complex, highly foliated corpus cerebelli. Asymmetry of the foliated cerebellum might be a common feature in rays of the myliobatiformes order. Intraspecific variation in the symmetry of the hypertrophed cerebellum in Myliobatis aquila [84] were reported by Voorhoeve [85] based on small sample size (1-3 animals), and variations in the cerebellar morphology have also been presented in the Atlantic stingray, Dasyatis sabina [86] by Puzdrowski and Leonard [87], but these variations were not connected to gender. Sexual dimorphism on the cerebellar foliation of $M$. japanica could be detected, however based on only a small number of studied specimens (10). Sexually dimorphic behaviors, such as mating, nursing, aggression, territorial behavior might be established and maintained by different neural circuits $[81,88]$ causing morphological differences in the cerebellar foliation between genders. Further investigation is needed whether the difference in the foliation is strongly related to sex or age, or it represents a random distribution. In anthropoid primates, mean female brain weight/body weight values are significantly greater than those of males due to secondary increases in body size in males, while no sexual dimorphism in body size has been described among odontocetes [57]. No sexual dimorphism could be detected in body weight of $M$. japanica, although the average brain weight was slightly higher in females.
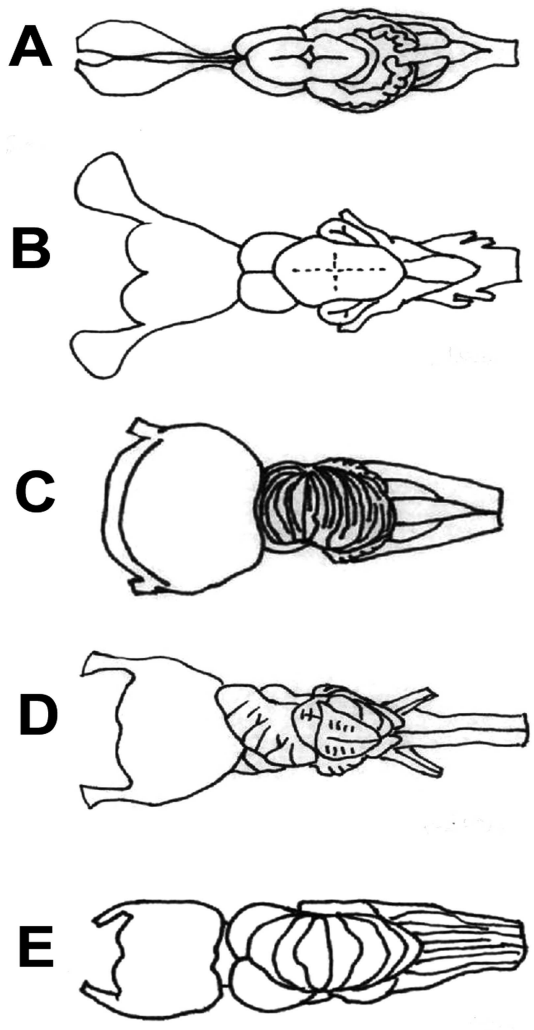

Fig. (6). Brain diagrams of four different radiations of cartilaginous fishes, dorsal aspect: A) a holocephalus (Callorhinchus millii); B) a squalomorph shark (Squalus acanthias) [7]; C) a galeomorph shark (Carcharinus leucas) [10]; D) and the brain of a myliobatiform ray (Myliobatis californica). E) Basking shark (Cetorhinus maximus) [47] brain is presented, as of a large bodied plankton feeder such as Mobulids. Brains are not to scale. For comparison see Fig. (2A, B) for M. japanica brain.

Fiebig [89] observed that visual responses predominate in the anterior lobe of the cerebellum, which is greatly hypertrophed in Mobula, and tactile responses in the posterior lobe in the thornback guitarfish. The auriculas were moderately developed in Mobulids, although it is well developed only in deep sea elasmobranchs with good lateral line sensation.

The cerebellum of the Mobula is most similar to that of lamniform and advanced carcharhiniform sharks (Fig. 6C), which possess a complexly convoluted cerebellum as well. In squalomorph sharks (Fig. 6B) the percentage of the cerebellum is around $19.4 \%$ of the total brain mass, similarly to that of Mobula, but the former's foliation is much simple than the latter one. Shark species with the relatively largest cerebella did not necessarily also exhibit the highest levels of foliation [9]. There is a trade-off in most species between relative cerebellar size and foliation, 
although not in the case of the most highly derived, highly active and maneuverable predators, such as Alopias, Sphyrna [9] and some myliobatids [10], especially Mobulids, according to the present study. Mobulids possessed the highest cerebellar foliation among batoids so far.

Other large-bodied filter-feeder sharks, such as Rhincodon typus and Cetorhinus maximus (Fig. 6E) also had large and highly foliated cerebellum [17]. Sharks with the most highly foliated cerebella are all wide-ranging, migratory species [9], which would imply that Mobulids might travel long distances, however there is only limited data available on the migratory behaviour of Mobulids as yet [90]. Cerebellar foliation appears to be related to high maneuverability $[9,91,92]$, locomotor abilities and sensorymotor integration as well [48], it is believed to reflect increased sociality and cognitive abilities [36, 40, 72] rather than prey capturing itself [83], which is particularly evident in the case of Mobulids.

\section{CONCLUSION}

Three species of Mobulid rays discussed in this paper possessed the highest brain weight/body weight ratio among batoids, with the highest telencephalic percentage of the total brain weight in $M$. japanica and the most foliated cerebella among batoids, while $M$. birostris possessed the highest brain weight among all fish. The gross morphology of their brains resembled the most to that of hammerhead sharks (Sphyrna), most likely due to the 3-dimensional habitat they live, their active and maneuverable lifestyles, highly developed social and migratory behavior, and possibly the increased ability of sensory processing thanks to the broad shape of their heads. Very little is known about the behavioral and learning capacities of the large-brained elasmobranchs, especially Mobulids, since these are very difficult to study in their natural environment. More research would be needed in order to clarify the capacities of these rays connected to the specific morphological characteristics of their brain.

\section{ACKNOWLEDGEMENTS}

Special thanks to the Portuguese Elasmobranch Association (www.apece.pt) and the Lisbon Aquarium, John'O Sullivan and the Monterey Bay Aquarium, Glenn R. Northcutt and the Scripps Institution of Oceanography for their support in the collecting expedition and providing equipment for the brain collection. The valuable data on the Manta brain was kindly provided by Georg Striedter. I'm grateful to Oscar Sosa Nishizaki, Ellen Freund and Joăo P. Correia for their help in the field work. I am grateful to Szilvia Kover, James Locascio and Antoneta Granic for their contribution in the mathematical analyses and Prof. Andras Csillag for the helpful revision of the manuscript.

\section{REFERENCES}

[1] Butler A, Hodos W. Comparative Vertebrate Neuroanatomy. John Wiley \& Sons Inc. Hoboken, New Jersey 1996.

[2] Jerison HJ. Evolution of the brain and intelligence, Academic Press, New York 1973.

[3] Bauchot R, Platel R, Ridet JM. Brain- body weight relationships in Selachii. Copeia 1976; 2: 305-10.

[4] Ebbesson SOE, Northcutt RG. Neurology of Anamniotic Vertebrates. In: Masterson RB, Campbell CBG, Bitterman ME, Hotton N, Eds. Evolution of the Brain and Behavior in Vertebrates: Hillsdale. New Jersey: Erlbaum 1976; pp. 115-46.
[5] Northcutt RG. Elasmobranch central nervous system organization and its possible evolutionary significance. Amer Zool 1977; 17: 411-29.

[6] Northcutt RG. In: Hodgson, Mathewson, Eds. Sensory biology of sharks, skates, and rays, Brain organization in the cartilaginous fishes. Office of Naval Research, Department of the Navy, Arlington 1978; 117-93.

[7] Smeets WJAJ, Nieuwenhuys R, Roberts BL. The Central Nervous System of Cartilaginous Fishes: Structural and Functional Correlations. New York: Springer-Verlag 1983.

[8] Myagkov NA. The brain sizes of living Elasmobranchii as their organization level indicator. I. General Analysis. J Hirnforsch 1991; 32: 553-61.

[9] Yopak K, Lisney TJ, Collin SP, Montgomery JC. Variation in brain organization and cerebellar foliation in Chondrichthyans: sharks and holocephalans. Brain Behav Evol 2007; 69: 280-300.

[10] Lisney TJ, Yopak KE, Montgomery JC, Collin SP. Variation in brain organization and cerebellar foliation in chondrichthyans: batoids. Brain Behav Evol 2008; 72(4): 262-82.

[11] Ebinger P, Wächtler K, Stähless S. Allometrical studies of the brain of Cyclostomes. J Hirnforsch 1983; 24: 545-50.

[12] Coles RJ. Natural history notes on the devil-fish, Manta birostris (Walbaum) and Mobula olfersi (Müller). Bull Am Mus Nat Hist 1916; 28: 337-48.

[13] Northcutt RG. Changing views of brain evolution. Brain Res Bull 2001; 55(6): 663-74.

[14] Ebbesson SOE. In: Ebbesson, Eds. Comparative neurology of the telencephalon, On the organization of the telencephalon in elasmobranchs, Plenum Press, New York 1980; 1-16.

[15] Lisney TJ, Collin SP. Brain morphology in large pelagic fishes: a comparison between sharks and teleosts. J Fish Biol 2006; 68: 53254.

[16] Lisney TJ, Bennett MB, Collin SP. Volumetric analysis of sensory brain areas indicates ontogenetic shifts in the relative importance of sensory systems in elasmobranchs. Raff Bull Zool 2007; 14: 7-15.

[17] Yopak KE, Frank LR. Brain size and brain organization of the whale shark, Rhincodon typus, using magnetic resonance imaging. Brain Behav Evol 2009; 74: 121-42.

[18] Masai H. On the brain pattern of Chlamydoselachus anguines. Yokahama Med Bull 1961; 12: 231-8.

[19] Masai H. On the external form of the brain of Heterodontus japanicus. Yokahama Med Bull 1962; 12: 249-57.

[20] Masai H. On the brain pattern of Heterodontus zebra. Jpn J Ichthyol 1963; 10: 20-23.

[21] Masai H, Sato Y, Aoki M. The brain of Mitsukurina owstoni. J Hirnforsch 1973; 14: 493-500.

[22] Myagkov NA. External structure of the cephalic brain of the pelagic shark, Squaliolus laticaudus, Voprosy Ikhtiologii, No. 1, $1988 ; 153-54$.

[23] Sato Y, Takatsuji K, Masai H. Brain organization of sharks, with special reference to archaic species. J Hirnforsch1983; 24: 289-95.

[24] Striedter GF. Principles of brain evolution. Sunderland, MA: Sinauer Associates, Inc. 2005.

[25] Alexander RL. Evidence of counter-current heat exchanger in the ray, Mobula tarapacana (Chondrichthyes: Elasmobranchii: Batoidea: Myliobatiformes). J Zool 1995; 237: 377-84.

[26] Alexander RL. Evidence of brain-warming in the mobulid rays, Mobula tarapacana and Manta birostris (Chondrichthyes: Elasmobranchii: Batoidea: Myliobatiformes). Zool J Linnean Soc 1996; 118: 151-64.

[27] Schweitzer J, Notarbartolo-Di-Sciara G. The rete mirabile cranica in the genus Mobula: A comparative study. J Morph 1986; 188, 2: $167-78$.

[28] Ari C, Kálmán M. Evolutionary changes of astroglia in Elasmobranchii comparing to Amniotes: a study based on three immunohistochemical markers (GFAP, S-100, and glutamine synthetase). Brain Behav Evol 2008; 71: 305-24.

[29] Ari C. On the Brain of Cartilaginous Fishes: Cerebralization, astroglial architecture and blood-brain barrier composition, LAP Lambert Academic Publishing, Germany 2009.

[30] Bauchot R, Bauchot ML, Platel R, Ridet JM. The brains of Hawaiian tropical fishes: Brain size and evolution. Copeia 1977; $1: 42-6$.

[31] Bauchot R, Ridet JM, Bauchot ML. The brain organization of butterfly fishes. In: Environ Biol Fishes, Balon EK, Motta PJ, Eds. Kluwer Academic Publishers, New York 1989; 205-19. 
[32] Kappers CUA, Huber GC, Crosby E. The Comparative Anatomy of the Nervous System of Vertebrates, including Man. New York: Macmillan 1936.

[33] Huber R, Rylander MK. In: Environmental Biology of Fishes, Balon EK, Weiser W, Schiemer F, Goldschmidt A, Kotrschal K, Eds., Brain morphology and turbitity preference in Notropis and releted genera (Cyprinidae, Teleostei). Dordrecht: Kluwer Academic Publishers 1992; vol. 33: pp. 153-65.

[34] Huber R, van Staaden MJ, Kaufman LS, Liem KF. Microhabitat use, trophic patterns and the evolution of brain sructure in African cichlids. Brain Behav Evol 1997; 50: 167-82.

[35] Kotrschal K, Palzenberger M. Neuroecology of cyprinids: comparative, quantitative histology reveals diverse brain patterns. Environ Biol Fishes 1992; 33: 135-152.

[36] Kotrschal K, van Staaden MJ, Huber R. Fish brains: evolution and environmental relationships. Rev Fish Biol Fish 1998; 8: 373-408.

[37] Schellart NAM, Prins M. Interspecific allometry of the teleost visual system: a new approach. Netherlands J Zool 1993; 43: 27495.

[38] Eisenberg JF, Wilson DE. Relative brain size and feeding strategies in the Chiroptera. Evolution 1978; 32: 740-51.

[39] Harvey MJ, Krebs JR. Comparing brains. Science 1990; 249: 140-

[40] Hutcheon JM, Kirsch JW, Garland T. A comparative analysis of brain size in relation to foraging ecology and phylogeny in the Chiroptera. Brain Behav Evol 2002; 60:165-80.

[41] Pirlot P, Jolicoeur P. Correlations between major brain regions in Chiroptera. Brain Behav Evol 1982; 20: 172-81.

[42] Müller J, Henle FGJ. Systematische Beschreibung der Plagiostomen. Berlin. Plagiostomen CAS Ref No.: 3069, 1838-41; 103-200.

[43] Lloyd. Report on the fish collected in Tibet by Capt. F. H. Stewart, I.M.S. Source: Rec. Indian Mus. Calcutta. 1908; vol. 2: pp. 341-4.

[44] Walbaum JJ. Petri Artedi sueci genera piscium. In quibus systema totum ichthyologiae proponitur cum classibus, ordinibus, generum characteribus, specierum differentiis, observationibus plurimis. Redactis speciebus 242 ad genera 52. Ichthyologiae pars III. Ant. Ferdin. Rose, Grypeswaldiae. Greifswald. Artedi Piscium 1792; 1723.

[45] Compagno LJV. In: Carpenter KE, Niem V, Eds. Mobulidae. Devil rays. FAO Identification Guide for Fishery Purposes. The Western Central Pacific 1997.

[46] Philippi RA. Abbildung und Beschreibung einiger Chilenischer Fische. Die rochen, Callorrhynchus und Orthagoriscus des Chilenischen meeres. F. A. Brockhaus, Leipzig. Chilenischer Fische 1892; 1-18.

[47] Kruska DCT. The brain of the basking shark (Cetorhinus maximus). Brain Behav Evol 1988; 32:353-63.

[48] New JG. Comparative neurobiology of the elasmobranch cerebellum: theme and variations on a sensorimotor interface. Environ Biol Fishes 2001; 60: 93-108.

[49] Northcutt RG. In: Evolutionary Biology of Primitive Fishes. Foreman RE, Gorbman A, Dodd JM, Olsson R, eds. The brain and sense organs of the earliest vertebrates: Reconstruction of a morphotype. Plenum, New York, 1985; 81-112.

[50] Northcutt RG. Brain variation and phylogenetic trends in elasmobranch fishes. J Exp Zool Suppl 1989; 2: 83-100.

[51] Demski LS, Northcutt RG. In: Klimley AP, Ainley DG, Eds. Great White Sharks: the biology of Carcharodon carcharias, The brain and cranial nerves of the white shark: an evolutionary perspective. San Diego, CA: Academic Press 1996; 121-30.

[52] Budeau DA, Verts BJ. Relative brain size and structural complexity of habitats of chipmunks. J Mammal 1986; 67: 579-81.

[53] Okada Y, Aoki M, Sato Y, Masai H. The brain patterns of sharks in relation to habit. J Hirnforsch 1969; 11: 347-65.

[54] Gunnerus JE. Brugden (Squalus maximus). Det Trondhiemske Selskabs Skrifter 1765; 33-49.

[55] Ito H, Yoshimoto M, Somiya H. External Brain Form and Cranial Nerves of the Megamouth Shark, Megachasma pelagios. Copeia No.1, 1999; 210-3.

[56] Griffith E, Smith CH. The class Pisces, arranged by the Baron Cuvier, with supplementary additions, by Edward Griffith FRS, and Lieut.-Col. Charles Hamilton Smith FR, LSS, London. Class Pisces, Cuvier 1834; 1-680.
[57] Marino L. A comparison of encephalization between Odontocete cetaceans and Anthropoid primates. Brain Behav Evol 1998; 51: 230-8.

[58] Myagkov NA, Fänge R. Some structural peculiarities of brain of greenland shark, Somniosus microcephalus (dalatiidae, Sualiformes) Zoologichesky Zhurnal, 62, No.6, 1983; 957-9.

[59] Ridet JM, Bauchot R, Delfini C. L'encéphale de Scyliorhinus canicula (Linne 1758) (Chondrichthyes, Selachii, Scyliorhinidae) Recherche d'une grandeur de reference pour des études quantitatives. Cahies de Biologie Marine, Roscoff 1973; 14: 11-28.

[60] Mlikovsky J. Ontogenetic mechanisms of the brain size evolution. Plzeňsky Lékasky Sbornik N 5. 1986; 45-8.

[61] Ridet JM. Les relations pondérales encephalo-somatiques chez les poissons téléostéens. Comptes Reendus le Academie des Sciences, Paris 1973; 276: 1437-40.

[62] Northcutt RG, Braford MR. In: Ebbesson SOE, Eds. Comparative neurology of the telencephalon, New observations on the telencephalon of actinopterygian fishes. Plenum Press, New York 1977.

[63] Platel R. Analyse volumétrique comparée des principales subdivisions encéphaliques chez les reptiles sauriens. J Hirnforsch 1976; 17: 513-37.

[64] Pritz MB, Northcutt RG. Succinate dehydrogenase activity in the telencephalon of crocodiles correlates with the projection areas of sensory thalamic nuclei. Brain Res 1977; 25, 124(2): 357-60.

[65] Klimley AP. Schooling in Sphyrna lewini, a species with a low risk of predation: a nonegalitarian state. J Comp Ethol 1985; 70: 297 319.

[66] Myrberg AAJ, Gruber S. The behavior of the bonnethead shark, Sphyrna tiburo. Copeia 1974; 358-74.

[67] Springer S. In: Sharks, Skates and Rays, Gilbert PW, Mathewson RF, Rall DP, Eds. Social organization of shark populations. Baltimore, MD: Johns Hopkins Press 1967; 149-74.

[68] Yano K, Sato F, Takahashi T. Observations of mating behavior of the manta ray, Manta birostris, at the Ogasawara Islands, Jpn Ichthyol Res 1999; 46: 289-96.

[69] Hayes JP, Garland TJr. The evolution of endothermy: testing the aerobic capacity model. Evolution 1995; 49: 839.

[70] Carey FG, Teal JM. Mako and porbeagle: warmbodied sharks. Comp Biochem Physiol 1969; 28: 199-204.

[71] Wourms JP. Reproduction and development in chondrichthyan fishes. Am Zool 1977; 17: 379-410.

[72] Barton RA, Purvis A, Harvey PH. Evolutionary radiation of visual and olfactory brain systems in primates, bats and insectivores. Phil Trans Res Soc London Bull 1995; 348: 381-92.

[73] Riddell WI, Corl KG. Comparative investigation and relationship between cerebral indices and learning abilities. Brain Behav Evol 1977; $14: 305-8$

[74] Deaner RO, Isler K, Burkart J, van Schaik C. Overall brain size, and not encephalization quotient, best predicts cognitive ability across non-human primates. Brain Behav Evol 2007; 70: 115-24.

[75] Ari C, Correia JP. Role of sensory cues on the food searching behaviour of a captive Manta birostris (Myliobatiformes, Mobulidae). Zoo Biol 2008; 27(4): 294-304.

[76] Rüppe WPES. Neue Wirbelthiere zu der Fauna von Abyssinien gehörig. Fische des Rothen Meeres. Frankfurt-am-Main. 1-148, Pls. 1-33. 1835:1-28, Pls. 1-7; 1836:29-52, Pls. 8-14; 1837:53-80, Pls 15-21; 1838:81-148, Pls. 22-33. Fische Rothen Meeres 1835-38.

[77] Bleeker P. Carcharias (Prionodon) amblyrhynchos, eene nieuwe haaisoort, gevangen nabij het eiland Solombo. Natuurwetenschappelijk Tijdschrift Voor Necterlandsch Indië, 1856; 467-8.

[78] Bodznick D, Northcutt RG. An electrosensory area in the telencephalon of the little skate, Raja erinacea. Brain Res 1984; 298: 117-24

[79] Tong SL, Bullock TH. The sensory functions of the cerebellum of the thornback ray, Platyrhinoidis triseriata. J Comp Physiol 1982; 148: 399-410.

[80] Paul DH, Roberts BL. The significance of cerebellar function for a reflex movement of the dogfish. J Comp Physiol 1979; 134: 69-74.

[81] Gluck MA, Allen MT, Myers CE, Thompson RF. Cerebellar substrates for error correction in motor conditioning. Neurobiol Learn Mem 2001; 76: 314-41.

[82] Montgomery J, Carton G, Bodznick D. Error-driven motor learning in fish. Biol Bull 2002; 203: 238-9. 
[83] Paulin MG. The role of the cerebellum in motor control and perception. Brain Behav Evol 1993; 41: 39-51.

[84] Linnaeus C. Systema Naturae, Ed. X. (Systema naturae per regna tria naturae, secundum classes, ordines, genera, species, cum characteribus, differentiis, synonymis, locis. Tomus I. Editio decima, reformata.) Holmiae. Systema Nat. ed. 10 i-ii +1758 ; 1 824.

[85] Voorhoeve JJ. Over den Bouw van de Kleine hersenen der Plagiostomen, Thesis, Univ. Amsterdam, 1917; 88.

[86] Lesueur CA. Description of several species of the Linnaean genus Raia, of North America. J Acad Nat Sci Phil 1824; 100-21.

[87] Puzdrowski RL, Leonard RB. Variations in cerebellar morphology of the Atlantic stingray, Dasyatis sabina. Neurosci Lett 1992; 3, 135: 196-200.

[88] Shah NM, Pisapia DJ, Maniatis S, Mendelsohn MM, Nemes A, Axel R. Visualizing sexual dimorphism report in the brain. Neuron 2004; 43: 313-9.
[89] Fiebig E. Connections of the corpus cerebelli in the thornback guitarfish, Platyrhinoidis triseriata (elasmobranchii): a study with WGA-HRP and extracellular granule cell recording. J Comp Neurol 1988; 286: 567-83.

[90] Dewar H, Mous P, Domeier M, Muljadi A, Pet J, Whitty J. Movements and site fidelity of the giant manta ray, Manta birostris, in the Komodo Marine Park, Indonesia. Mar Biol 2008; 155: 121-33.

[91] Donley JM, Shadwick RE. Steady swimming muscle dynamics in the leopard shark Triakis semifasciata. J Exp Biol 2003; 206: 1117 26.

[92] Wilga CAD, Lauder GV. In: Biology of Sharks and Their Relatives, Carrier JC, Musick JA, Heithaus MR, Eds. Biomechanics of locomotion in sharks, rays, and chimaeras. London: CRC Press 2004; 139-202.

(C) Csilla Ari; Licensee Bentham Open.

This is an open access article licensed under the terms of the Creative Commons Attribution Non-Commercial License (http://creativecommons.org/licenses/by-nc/ 3.0/) which permits unrestricted, non-commercial use, distribution and reproduction in any medium, provided the work is properly cited. 